OPEN ACCESS

Edited by: Daniel Agardh,

Lund University, Sweden

Reviewed by:

Elena Verdu,

McMaster University, Canada

Shuo-Wang Qiao,

University of Oslo, Norway

${ }^{*}$ Correspondence:

Glennda Smithson

glennda.smithson@takeda.com

Specialty section: This article was submitted to

Mucosal Immunity,

a section of the journal

Frontiers in Immunology

Received: 08 February 2021

Accepted: 19 March 2021

Published: 07 April 2021

Citation:

Smithson G, Siegelman J, Oki T, Maxwell JR and Leffler DA (2021) The

Evolving Landscape of Biomarkers

in Celiac Disease: Leading the Way

to Clinical Development.

Front. Immunol. 12:665756.

doi: 10.3389/fimmu.2021.665756

\section{The Evolving Landscape of Biomarkers in Celiac Disease: Leading the Way to Clinical Development}

\author{
Glennda Smithson ${ }^{1 *}$, Jenifer Siegelman ${ }^{1}$, Toshihiko Oki ${ }^{1}$, Joseph R. Maxwell ${ }^{1}$ \\ and Daniel A. Leffler ${ }^{1,2}$ \\ ${ }^{1}$ Research and Development, Takeda Pharmaceuticals Inc. Co., Cambridge, MA, United States, ${ }^{2}$ Celiac Disease Research \\ Program, Harvard Medical School, Boston, MA, United States
}

Celiac disease is a common immune-mediated disease characterized by abnormal T-cell responses to gluten. For many patients, symptoms and intestinal damage can be controlled by a gluten-free diet, but, for some, this approach is not enough, and celiac disease progresses, with serious medical consequences. Multiple therapies are now under development, increasing the need for biomarkers that allow identification of specific patient populations and monitoring of therapeutic activity and durability. The advantage of identifying biomarkers in celiac disease is that the underlying pathways driving disease are well characterized and the histological, cellular, and serological changes with gluten response have been defined in gluten challenge studies. However, there is room for improvement. Biomarkers that measure histological changes require duodenal biopsies and are invasive. Less invasive peripheral blood cell and cytokine biomarkers are transient and dependent upon gluten challenge. Here, we discuss established biomarkers and new approaches for biomarkers that may overcome current limitations.

Keywords: celiac disease, biomarkers, patient populations, diagnosis, disease monitoring, clinical development

\section{INTRODUCTION}

Celiac disease $(\mathrm{CeD})$ is a chronic disease mediated by a destructive immune response triggered by gliadin, a protein found in wheat, rye, and barley. The response to gliadin is characterized by activation of gliadin-specific $\mathrm{T}$ cells, anti-gliadin and tissue transglutaminase antibody response, and small intestine inflammation and damage to the epithelium resulting in a characteristic villous flattening (1). Biopsy-confirmed $\mathrm{CeD}$ currently has a worldwide prevalence of $0.7 \%$ and has been increasing in prevalence over the last 3 decades (2).

In most patients, eliminating gluten from the diet (gluten-free diet; GFD) reduces symptoms and recurring intestinal damage. However, for about $30 \%$ of patients, gluten restriction is not sufficient

Abbreviations: CeD, celiac disease; GFD, gluten-free diet; IEL, intraepithelial lymphocyte; $\gamma \mathrm{IFN}$, gamma interferon; IHC, immunohistochemistry; HLA, human leukocyte antigen; PBMC, peripheral blood mononuclear cell; PD, pharmacodynamic; $\mathrm{RCD}$, refractory celiac disease; RCD1, RCD type 1; RCD2, RCD type 2; TCR, T-cell receptor; TTG-IgA, IgA antibodies against tissue transglutaminase; VCE, video capsule endoscopy; Vh:Cd, villous height:crypt depth. 
to prevent symptoms or damage $(3,4)$. This lack of response is most commonly due to repeated inadvertent gluten exposure and/or high sensitivity to gluten at levels below what is considered 'gluten free' [20 ppm; (5)], but, in rare cases, may be related to refractory celiac disease (RCD). A diagnosis of RCD is based on continued intestinal damage and malabsorption after $\geq 12$ months on a GFD. RCD1 is similar to active CeD with CD3+ polyclonal $\mathrm{T}$ cells comprising the majority of intraepithelial lymphocytes. Often, this disease type improves over time with strict adherence to a GFD. RCD2, in contrast, is characterized by the clonal expansion of aberrant intraepithelial lymphocytes that do not express surface CD3 or a T-cell receptor. These patients have a much poorer prognosis, with higher mortality and likelihood of progressing to enteropathyassociated T-cell lymphoma (3, 6-8).

There are currently no approved therapies for $\mathrm{CeD}$; however, there are several therapies in development. Larazotide acetate (INN-202) is the most advanced program and is currently in phase III (ClinicalTrials.gov identifier: NCT03569007). Phase I/ II programs include TAK-062 (ClinicalTrials.gov identifier: NCT03701555) and latiglutenase (IMGX003), which degrade ingested gliadin (9); PRV-015 (AMG 714), a monoclonal antibody that blocks IL-15, a cytokine associated with mucosal damage (10); and TAK-101, which elicits gliadin-specific immune tolerance. These therapies may target patients who are on a GFD but have ongoing symptoms and/or intestinal damage due to inadvertent gluten exposure. Currently, a diverse range of mechanisms is being investigated (11), and it is possible that selected therapeutics could be used for a broader segment of the patient population.

As the number of promising therapies for CeD grows, so does the need to measure therapeutic impact on clinically relevant endpoints and distinguish between different patient populations. This could be addressed, at least in part, by thoughtful biomarker selection. The Biomarkers, EndpointS and other Tools resource glossary (12) defines a biomarker as " $A$ defined characteristic that is measured as an indicator of normal biological processes, pathogenic processes, or responses to an exposure or intervention, including therapeutic interventions. Molecular, histologic, radiographic, or physiologic characteristics are types of biomarkers. A biomarker is not an assessment of how a patient feels, functions, or survives". In this review, we describe the context of use and limitations of current biomarkers, and how new biomarkers under development may avoid these limitations and play an important part in the clinical development of new therapies.

\section{PROGNOSTIC BIOMARKERS AND PREDICTING THE COURSE OF CeD}

Prognostic biomarkers provide information about the likelihood of a clinical event, disease recurrence, or disease progression within a patient population (12). For example, a prognostic biomarker in $\mathrm{CeD}$ might predict if a patient had a greater likelihood of a negative response to gluten exposure, or was more likely to progress to a serious disease state such as RCD. Some, but not all, prognostic biomarkers are also predictive biomarkers, allowing the selection of patients who are more likely to have a favorable/unfavorable response to a specific therapy.

Human leukocyte antigen (HLA) class II has been proposed to be a prognostic genetic biomarker for CeD severity (Table 1) (9, 10, 13-30). Either HLA-DQ2.5 (encoded by the HLA-DQA allele, $H L A-D Q A 1^{\star} 05$ and HLA-DQB allele $\left.H L A-D Q B 1^{\star} 02\right)$, HLA-DQ2.2 (HLA-DQA $1^{*} 02$ and $H L A-D Q B 1{ }^{*} 02$ alleles), or HLA-DQ8 ( $H L A-D Q A 1^{*} 03$ and $H L A-D Q B 1^{*} 03: 02$ alleles) are present in almost all patients with CeD (31). HLA-DQ2 and/or HLA-DQ8, expressed on antigen-presenting cells, bind to immunogenic gliadin peptides and activate gliadin-specific CD4+ effector T cells (1). HLA-DQ2.5 binds and presents immunogenic gliadin peptides more effectively than HLA-DQ8 and HLA-DQ2.2 $(32,33)$. Homozygosity of the HLA-DQB1 ${ }^{\star} 02$ allele, which encodes the beta chain of HLA-DQ2, may impact the number of gliadin-specific $T$ cells that are activated after gluten exposure. Patients with HLA-DQ2 who are homozygous for the $H L A-D Q B 1^{\star} 02$ allele appear more likely to respond to a gluten challenge with increased serum IL-2 and to have higher maximum serum concentrations of IL-2 than other genotypes $(24,34)$. In turn, this subset of patients may have a slower intestinal recovery rate after gluten challenge (14) and may be more likely to progress to RCD2 (35). These findings support HLA DQB $1^{\star} 02$ homozygosity as a determinant of gluten response and a potential prognostic biomarker for predicting the course of disease. Similar findings have not been associated with the gene for the alpha chains of HLA-DQ2.5, or HLADQ2.2, or the genes for the alpha or beta chains of HLA-DQ8.

The link between $H L A-D Q B 1^{*} 02$ homozygosity and disease severity or progression to more complicated disease has not been seen in all populations $(36,37)$. Whether this discrepancy is a biologically relevant observation showing a lack of prognostic power in the number of $H L A-D Q B 1^{\star} 02$ alleles in these populations, or is a result of a small patient number, biased patient selection, or differences in study protocol, requires further investigation.

\section{DIAGNOSTIC BIOMARKERS AND PATIENT SELECTION FOR CLINICAL TRIALS}

In $\mathrm{CeD}$, diagnostic biomarkers could be used to confirm that an individual has $\mathrm{CeD}$ and not another disease, such as irritable bowel syndrome, that clinically mimics symptoms of $\mathrm{CeD}$ (38, 39). They could also be used to distinguish between disease subtypes, for example patients with active $\mathrm{CeD}$ due to inadvertent gluten exposure versus patients with RCD1, just as current biomarkers allow for differentiation of RCD1 from RCD2 as described later (40). Distinguishing between patient subpopulations is important because some therapies, such as 
TABLE 1 | Biomarkers used in celiac studies.

\begin{tabular}{|c|c|c|c|c|c|}
\hline Biomarker & Biomarker type ${ }^{a}$ & $\begin{array}{l}\text { Context of use in clinical } \\
\text { studies }\end{array}$ & Sample type (collected) & Assay $^{b}$ & $\begin{array}{l}\text { Representative clinical } \\
\text { studies }^{c}\end{array}$ \\
\hline HLA-DQ2 and/or HLA-DQ8 & $\begin{array}{l}\text { Prognostic } \\
\text { Diagnostic }\end{array}$ & Confirm diagnosis & $\begin{array}{l}\text { DNA (blood cells or cheek } \\
\text { swab) }\end{array}$ & Molecular assay (13) & $(10,14)$ \\
\hline Villous height:crypt depth ratio & $\begin{array}{l}\text { Diagnostic } \\
\text { Pharmacodynamic } \\
\text { Monitoring }\end{array}$ & $\begin{array}{l}\text { Confirm diagnosis } \\
\text { Monitor response to therapy }\end{array}$ & Protein (mucosal biopsy) & $\mathrm{IHC}(15)$ & $(9,10)$ \\
\hline IEL count & $\begin{array}{l}\text { Diagnostic } \\
\text { Pharmacodynamic } \\
\text { Monitoring }\end{array}$ & $\begin{array}{l}\text { Confirm diagnosis } \\
\text { Monitor response to therapy }\end{array}$ & Protein (mucosal biopsy) & $\mathrm{IHC}(15)$ & $(9,10)$ \\
\hline $\begin{array}{l}\text { Celiac serology } \\
\text { TTG-IgA level }\end{array}$ & $\begin{array}{l}\text { Diagnostic } \\
\text { Pharmacodynamic } \\
\text { Monitoring }\end{array}$ & $\begin{array}{l}\text { Confirm diagnosis } \\
\text { Determine if gluten exposure has } \\
\text { occurred }\end{array}$ & Protein (serum) & ELISA (16) & $(9,10,17)$ \\
\hline $\begin{array}{l}\text { Number of HLA-DQ2 restricted gluten peptide binding } \\
\text { CD4 T cells }\end{array}$ & $\begin{array}{l}\text { Diagnostic } \\
\text { Pharmacodynamic } \\
\text { Monitoring }\end{array}$ & Gluten-specific T-cell response & Protein (blood cells) & $\begin{array}{l}\text { HLA-tetramer binding measured by flow } \\
\text { cytometry (18) }\end{array}$ & $(19,20)$ \\
\hline $\begin{array}{l}\text { Production of } \gamma \mathrm{F} F \mathrm{~N} \text { in response to ex vivo blood cell } \\
\text { culture with } \\
\text { gluten peptides (number of spot-forming units) }\end{array}$ & $\begin{array}{l}\text { Pharmacodynamic } \\
\text { Monitoring }\end{array}$ & Gluten-specific T-cell response & $\begin{array}{l}\text { Protein (blood cells; } \\
\text { PBMC) }\end{array}$ & rIFN ELISpot (21) & $(20,22)$ \\
\hline $\begin{array}{l}\text { Production of IP-10 in response to ex vivo culture with } \\
\text { gluten peptides }\end{array}$ & $\begin{array}{l}\text { Pharmacodynamic } \\
\text { Monitoring }\end{array}$ & Gluten-specific T-cell response & $\begin{array}{l}\text { Protein (blood cells; } \\
\text { PBMC) }\end{array}$ & IP-10 ELISA (23) & (23) \\
\hline Change in IL-2 with oral gluten challenge & $\begin{array}{l}\text { Diagnostic } \\
\text { Pharmacodynamic } \\
\text { Monitoring }\end{array}$ & Gluten-induced immune response & Protein (serum or plasma) & Ultrasensitive ligand binding assays (24) & $(20,25)$ \\
\hline Change in gut-homing $\gamma \delta$ T cells and CD $8 \alpha \beta$ T cells & $\begin{array}{l}\text { Pharmacodynamic } \\
\text { Monitoring }\end{array}$ & Gluten-induced immune response & $\begin{array}{l}\text { Protein (blood cells; } \\
\text { PBMC) }\end{array}$ & Mass cytometry or flow cytometry (26) & $(20,26)$ \\
\hline RCD2 aberrant lymphocytes per total IELS & $\begin{array}{l}\text { Diagnostic } \\
\text { Pharmacodynamic }\end{array}$ & $\begin{array}{l}\text { Confirm diagnosis } \\
\text { Monitor response to therapy }\end{array}$ & Flow cytometry or $\mathrm{IHC}$ & Flow cytometry (27) & (28) \\
\hline $\begin{array}{l}\text { NKp46 positive IELs/100 epithelial cells } \\
\text { Celiac minutes of enteropathy }\end{array}$ & $\begin{array}{l}\text { Diagnostic } \\
\text { Diagnostic } \\
\text { Pharmacodynamic } \\
\text { Monitoring }\end{array}$ & $\begin{array}{l}\text { Confirm diagnosis } \\
\text { Extent of villous damage }\end{array}$ & $\begin{array}{l}\text { IHC } \\
\text { Optical images }\end{array}$ & $\begin{array}{l}\text { (29) } \\
\text { VCE (30) }\end{array}$ & $\begin{array}{l}\text { None } \\
(20)\end{array}$ \\
\hline
\end{tabular}

IEL, intraepithelial lymphocyte; $\gamma$ IFN, gamma interferon; IHC, immunohistochemistry; HLA, human leukocyte antigen; PBMC, peripheral blood mononuclear cell; RCD, refractory celiac disease; TTG-IgA, IgA antibodies against tissue transglutaminase; VCE, video capsule endoscopy.

${ }^{a}$ FDA-NIH Biomarker Working Group. BEST (Biomarkers, EndpointS, and other Tools) Resource [Internet]. Silver Spring (MD): Food and Drug Administration (US); 2016-. Available from: https://www.ncbi.nlm.nih. gov/books/NBK326791/ Copublished by National Institutes of Health (US), Bethesda (MD).

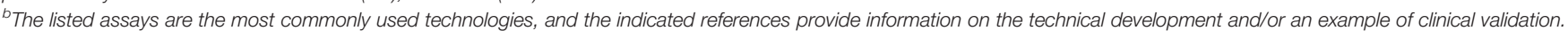

${ }^{c}$ Representative clinical studies are studies where the indicated biomarker was included as part of the protocol and prospectively collected. 
enzymes that degrade gluten, may be effective at blocking intestinal damage in a patient with disease driven by gluten exposure. However, a patient with RCD2, in whom intestinal damage occurs in the absence of gluten exposure, would have continuing pathological changes despite this type of therapy.

Currently, diagnosis of patients with $\mathrm{CeD}$ is based on serology, histology, and genetic biomarkers (e.g. HLA-DQ). In patients on a gluten-containing diet, detection of high titers of IgA antibodies against tissue transglutaminase (TTG-IgA) alone may be sufficient for a diagnosis of $\mathrm{CeD}(16,41,42)$. However, up to $5 \%$ of the Western population follow a GFD as a lifestyle choice (43), and, once a patient is on a GFD, antibodies to TTG and deamidated gliadin peptide subside and serology cannot be used for diagnosis. Confirmation of diagnosis in seropositive and seronegative patients is based on histology of duodenal biopsies and HLA typing (42). HLA-DQ2 or HLA-DQ8 expression alone is not sufficient for disease diagnosis because these are common HLA haplotypes, particularly in Western populations. Therefore, as diagnostic biomarkers, HLA-DQ2 or HLA-DQ8 alone have a negative predictive value of near $100 \%$, but have a negligible positive predictive value $(44,45)$.

For clinical trial design, these biomarkers have been used in combination to help verify $\mathrm{CeD}$ diagnosis, for patient stratification and as part of assessment of disease activity (e.g. active disease, well-controlled disease). In the phase II studies for latiglutenase and larazotide, celiac serology was used to estimate gluten exposure and to identify patients likely to have active disease $(9,17)$. In addition to celiac serology, the latiglutenase and the AMG 714 phase IIa studies used duodenal histology to characterize epithelial damage, based on villous height:crypt depth ratio (Vh:Cd) and intestinal inflammation as assessed by intraepithelial lymphocyte (IEL) counts (10). In the latiglutenase study, patients were selected based on $\mathrm{Vh}: \mathrm{Cd}$ of $\leq 2$ and were stratified based on serology (9). The success or failure of these biomarkers to reduce variability and segregate patients into clinically meaningful and therapeutically important populations is difficult to assess because neither study met its primary endpoint. However, it is notable that in the latiglutenase study, a post hoc analysis found that seropositive patients preferentially showed symptomatic relief compared with seronegative patients (46).

The clinical manifestations of $\mathrm{CeD}$ vary widely between patients, as does the pathophysiologic response to gluten exposure. This variability presents a challenge to detecting therapeutic response in clinical studies. To directly reduce variability in patient response, gluten challenge has been incorporated into clinical trials $(10,47)$. By challenging patients with a specific gluten dose regimen, the temporal changes induced by gluten and the impact of therapy can be measured with a variety of disease-relevant biomarkers as described later. For this type of study, it is critical to know that a patient with $\mathrm{CeD}$ has the potential for a robust response to gluten. However, patients recruited into these studies are on a GFD for $\geq 6-12$ months and are often intentionally selected based on negative celiac serology. Thus, only intestinal damage and HLA are currently widely available for use as indicators of disease status in these patients, and neither of these tests for a functional gliadin immune response.

One recent innovation, the HLA-DQ-gluten tetramer-based diagnostic assay, has been shown to differentiate patients with $\mathrm{CeD}$ from healthy controls, and to differentiate patients on a GFD from those who have recently ingested gluten. Overall, this assay is both sensitive and specific for identifying patients with $\mathrm{CeD}$, regardless of diet. The HLA tetramers, major histocompatibility complex class II molecules loaded with immunogenic peptides, used in the assay have to be from the same HLA-DQ haplotype as those in the patient being tested. HLA-DQ2.5, HLA-DQ8, and HLA-DQ2.2 tetramers have been produced by academic groups, suggesting that the majority of patients with $\mathrm{CeD}$ could be tested $(32,48,49)$. However, the assay takes a substantial amount of blood to perform, HLA-DQ tetramers are not commercially available and it is laborintensive, suggesting it may not be feasible as a clinical diagnostic tool (50). A second approach exploits the fact that CD4 T-cell clonotypes are long-lived and persist for decades in patients with $\mathrm{CeD}$ (51). This assay sequences the rearranged $\mathrm{T}$ cell receptor (TCR) $\beta$ chain T cells and was shown to imply a diagnosis of $\mathrm{CeD}$, based on TCR sequences common to patients with $\mathrm{CeD}$ (e.g. public sequences). The proof of principle was done using lamina propria $\mathrm{T}$ cells enriched with gluten-specific CD4 T cells; however, the ultimate goal of this approach will be to do the same assay in blood (52). The utility of these assays to confirm disease status as part of a clinical trial has yet to be tested.

Diagnosis of CeD subtype (uncontrolled CeD, RCD1, RCD2) is also key for the development of therapies, because the mechanisms driving each disease subtype may differ and, particularly for RCD2, which has a high mortality, the benefitrisk profile is quite different. RCD1 cannot be distinguished from gluten-induced active CeD via biomarkers. However, RCD2 can be identified based on biomarkers. The RCD2 IEL population is distinct from the polyclonal CD3+, CD8+ IELs associated with inflammation and damage after gluten challenge. RCD2 IELs are clonal TCR rearrangements and are positive for NKp46, tend to be CD8- and do not express surface CD3 or TCRs $(29,40)$. In a single phase IIa study, the safety and efficacy of anti-IL-15 (AMG 714) were tested in patients with RCD2. Patients were selected based on the percentage of aberrant IELs/100 total CD45+ IELs by flow cytometric analysis or $>50 \%$ aberrant IELs as measured by immunohistochemistry. This study did not meet the primary endpoint, reduction of aberrant intraepithelial lymphocytes from baseline measured at 12 weeks (28).

\section{PHARMACODYNAMIC BIOMARKERS AND MEASURING THERAPEUTIC INTERVENTION IN CeD}

Pharmacodynamic (PD) biomarkers measure the impact of therapeutic intervention on a biological process. In the development of therapies for $\mathrm{CeD}, \mathrm{PD}$ biomarkers could be 
used to evaluate therapeutic target engagement, gluten exposure or measure clinically meaningful endpoints, such as change in gluten-specific T cells and resolution of intestinal damage. Some PD markers can be tested serially to monitor drug-mediated changes over time and durability of therapeutic-induced responses to help build a rationale for a dosing regimen. A caveat for these PD biomarkers is that serial collection should have minimal impact on patient comfort or safety, thus, less invasive blood-based or imaging biomarkers are favored over duodenal biopsies.

PD biomarkers used in previous $\mathrm{CeD}$ clinical trials quantitatively measured changes in small intestine epithelial damage and inflammation by histology and evaluated immune response to gluten exposure by serology $(9,10)$. As a PD marker, histology has the advantage of measuring changes that are directly related to $\mathrm{CeD}$ processes, the influx of $\mathrm{T}$ cells into the epithelium, and the subsequent destruction of mucosal epithelium. Moving from the use of a subjective scoring system (such as Marsh-Oberhuber grade) to a quantitative evaluation of intestinal changes (e.g. measuring $\mathrm{Vh}: \mathrm{Cd}$ ratio and IEL numbers), provides the sensitivity to detect relatively small, but clinically significant damage $(15,53)$. Vh:Cd is currently the standard for mucosal assessment in $\mathrm{CeD}$ clinical trials and is more reliable and responsive than traditional subjective histological measures. However, reliance on Vh:Cd has several limitations, including: mucosal biopsies are invasive and unsuited for serial testing, duodenal biopsy provides only a small representation of the entire disease area, expertise and significant time is needed to properly orient tissue sections, and Vh:Cd does not include a measure of lymphocytosis (34). Video capsule endoscopy (VCE) avoids these issues. It is less invasive than a duodenal biopsy and can be used as a method to monitor therapeutic impact while evaluating a much larger portion of the small intestine. VCE is unable to directly measure cellular changes, but rather records macroscopic changes in tissue $(20,30)$.

Anti-TTG antibodies have been used as a PD biomarker to understand immune response to gluten challenge $(19,20,54)$ and have been incorporated into clinical trials for this purpose $(9,10)$. These antibodies are not considered by most to be pathogenic in the intestinal damage seen in $\mathrm{CeD}$, but may be a contributor to extraintestinal manifestations, such as dermatitis herpetiformis or central nervous system lesions (55-57). Antibody response requires repeated gluten exposure, takes at least 2 weeks to appear after initial gluten challenge, and is still high 3-4 weeks after the last gluten exposure $(20,54)$. Although anti-TTG antibody measurement is useful for $\mathrm{CeD}$ diagnosis, it is certainly not a dynamic biomarker. In comparison, newer cytokine and cellular PD biomarkers are more responsive to gluten, with changes seen in days or hours after gluten challenge, quickly dropping to pre-gluten challenge levels. After a single gluten dose in patients on a GFD, levels of several inflammatory cytokines increase (58). IL-2 is one of the most consistently upregulated cytokines in patients and peaks 4 hours after gluten challenge, becoming undetectable in most patients by 6 days after initial gluten exposure (20). The presence of IL-2 in patients correlated with CeD symptoms, and no changes in IL-2 were seen in healthy participants with gluten challenge $(58,59)$.

Gluten-specific CD4 T cells are released into the blood 6 days after the start of a gluten challenge $(20,22)$. Gluten-specific $\mathrm{T}$ cells can be induced by ex vivo antigen challenge with gluten peptides and quantified by $\gamma$ IFN ELISpot, IP-10 ELISA or visualized by flow cytometry using HLA-DQ2 tetramers in combination with CD38 expression (60). The results of these assays correlate well with each other $(22,23,50)$. As biomarkers for use in clinical trials, they have some pragmatic challenges: they require viable blood cells, reagents that are not commercially available, and large volumes of blood and CD4+ T-cell enrichment (tetramer assay only). However, the role of these gluten-specific CD4 T cells in CeD is clear, and a reduction in these cells would be highly suggestive of a diseasemodifying effect.

Along with gluten-specific $\mathrm{T}$ cells that arise after gluten challenge, gut-homing $\mathrm{CD} 8 \alpha \beta \mathrm{T}$ cells and $\gamma \delta \mathrm{T}$ cells that coexpress CD103 and the activation antigen, CD38, also increase 6 days after the start of a gluten challenge. Although the role of these cells in CeD is less well understood, the gut-homing CD8 T cells are phenotypically similar to IELs found in patients with active CeD (26). The advantage of tracking these cells as a PD biomarker of active disease is that they are more plentiful in the blood and do not require pre-enrichment or cell culture prior to staining.

\section{DISCUSSION}

Translational medicine and biomarkers are becoming integral components of clinical development, contributing to trials by: 1) supporting dose and dose regimen selections for new therapeutic modalities that preclude traditional pharmacokinetic measures; 2) confirming unique therapeutic mechanisms of action; 3) providing proof of concept earlier in development; and 4) showing therapeutic efficacy in trials that require fewer patients. Because the etiology of $\mathrm{CeD}$ is better understood than that of most chronic inflammatory diseases, it has been possible to design biomarker assays that allow quantification of the earliest changes induced by gluten ingestion, tracking of the adaptive immune response, and evaluation of tissue inflammation and damage. However, biomarkers have some limitations in a real-world setting, and are only one approach to understanding disease progression and therapeutic efficacy (61). With advances in technology and the discovery of new biomarkers, it is possible that, in future studies, patient selection can be based on specific disease subtypes, or on prognosis, identifying the patient subpopulation most appropriate for the benefit-risk profile of a given therapy. From early clinical studies, pharmacokinetic data and data from PD markers can be combined to model the therapeutic dose response and gain a deeper understanding of the therapeutic mechanism of action. 


\section{AUTHOR CONTRIBUTIONS}

GS, JM, and DL were responsible for the conceptualization of the manuscript. GS wrote the original draft. All authors reviewed and edited the manuscript. All authors contributed to the article and approved the submitted version.

\section{REFERENCES}

1. Jabri B, Sollid LM. T cells in celiac disease. J Immunol (2017) 198:3005-14. doi: 10.4049/jimmunol.1601693

2. Singh P, Arora A, Strand TA, Leffler DA, Catassi C, Green PH, et al. Global prevalence of celiac disease: systematic review and meta-analysis. Clin Gastroenterol Hepatol (2018) 16:823-36.e2. doi: 10.1016/j.cgh.2017.06.037

3. Leffler DA, Dennis M, Hyett B, Kelly E, Schuppan D, Kelly CP. Etiologies and predictors of diagnosis in nonresponsive celiac disease. Clin Gastroenterol Hepatol (2007) 5:445-50. doi: 10.1016/j.cgh.2006.12.006

4. Leonard MM, Cureton P, Fasano A. Indications and use of the gluten contamination elimination diet for patients with non-responsive celiac disease. Nutrients (2017) 9:1129. doi: 10.3390/nu9101129

5. Food and Agriculture Organization of the United Nations. World Health Organization. Standard for foods for special dietary use for persons intolerant to gluten. Codex Stan 118-1979. Adopted in 1979. Amendment: 1983 and 2015. Revision. (2008). Available at: http://www.fao.org/fao-whocodexalimentarius/sh-proxy/en/?lnk=1\&url=https $\% 253 \mathrm{~A} \% 252 \mathrm{~F} \%$ 252Fworkspace.fao.org\%252Fsites\%252Fcodex $\% 252$ FStandards $\% 252$ FCXS\% 2B118-1979\%252FCXS_118e_2015.pdf

6. El Khoury D, Balfour-Ducharme S, Joye IJ. A review on the gluten-free diet: technological and nutritional challenges. Nutrients (2018) 10:1410. doi: 10.3390/nu10101410

7. Green PH, Cellier C. Celiac disease. N Engl J Med (2007) 357:1731-43. doi: 10.1056/NEJMra071600

8. Rubio-Tapia A, Kelly DG, Lahr BD, Dogan A, Wu TT, Murray JA. Clinical staging and survival in refractory celiac disease: a single center experience. Gastroenterology (2009) 136:99-107. doi: 10.1053/j.gastro.2008.10.013

9. Murray JA, Kelly CP, Green PHR, Marcantonio A, Wu TT, Maki M, et al. No difference between latiglutenase and placebo in reducing villous atrophy or improving symptoms in patients with symptomatic celiac disease. Gastroenterology (2017) 152:787-98.e2. doi: 10.1053/j.gastro.2016.11.004

10. Lahdeaho ML, Scheinin M, Vuotikka P, Taavela J, Popp A, Laukkarinen J, et al. Safety and efficacy of AMG 714 in adults with coeliac disease exposed to gluten challenge: a phase $2 \mathrm{a}$, randomised, double-blind, placebo-controlled study. Lancet Gastroenterol Hepatol (2019) 4:948-59. doi: 10.1016/S2468-1253(19)30264-X

11. Kivela L, Caminero A, Leffler DA, Pinto-Sanchez MI, Tye-Din JA, Lindfors K. Current and emerging therapies for coeliac disease. Nat Rev Gastroenterol Hepatol (2021) 18(3):181-95. doi: 10.1038/s41575-020-00378-1

12. Fda-Nih Biomarker Working Group. BEST (Biomarkers, EndpointS, and other Tools) Resource. Silver Spring, MD: Food and Drug Administration (US) (2016). Co-published by National Institutes of Health (US), Bethesda (MD). Available at: https://www.ncbi.nlm.nih.gov/books/NBK326791/.

13. Choung RS, Mills JR, Snyder MR, Murray JA, Gandhi MJ. Celiac disease risk stratification based on HLA-DQ heterodimer (HLA-DQA1 DQB1) typing in a large cohort of adults with suspected celiac disease. Hum Immunol (2020) 81:59-64. doi: 10.1016/j.humimm.2020.01.006

14. Karinen H, Karkkainen P, Pihlajamaki J, Janatuinen E, Heikkinen M, Julkunen R, et al. Gene dose effect of the DQB1*0201 allele contributes to severity of coeliac disease. Scand J Gastroenterol (2006) 41:191-9. doi: 10.1080/00365520500206277

15. Taavela J, Koskinen O, Huhtala H, Lahdeaho ML, Popp A, Laurila K, et al. Validation of morphometric analyses of small-intestinal biopsy readouts in celiac disease. PloS One (2013) 8:e76163. doi: 10.1371/journal.pone.0076163

16. Penny HA, Raju SA, Lau MS, Marks LJ, Baggus EM, Bai JC, et al. Accuracy of a no-biopsy approach for the diagnosis of coeliac disease across different adult cohorts. Gut (2020) 2;gutjnl-2020-320913. doi: 10.1136/gutjnl-2020-320913

17. Kelly CP, Green PH, Murray JA, Dimarino A, Colatrella A, Leffler DA, et al. Larazotide acetate in patients with coeliac disease undergoing a gluten

\section{FUNDING}

This study was sponsored by Takeda Pharmaceutical Company Ltd. Editorial support was provided by Oxford PharmaGenesis, Oxford, UK and was funded by Takeda Pharmaceutical Company Ltd.

challenge: a randomised placebo-controlled study. Aliment Pharmacol Ther (2013) 37:252-62. doi: 10.1111/apt.12147

18. Quarsten H, Mcadam SN, Jensen T, Arentz-Hansen H, Molberg O, Lundin $\mathrm{KE}$, et al. Staining of celiac disease-relevant $\mathrm{T}$ cells by peptide-DQ2 multimers. J Immunol (2001) 167:4861-8. doi: 10.4049/jimmunol. 167.9.4861

19. Sarna VK, Skodje GI, Reims HM, Risnes LF, Dahal-Koirala S, Sollid LM, et al. HLA-DQ:gluten tetramer test in blood gives better detection of coeliac patients than biopsy after 14-day gluten challenge. Gut (2018) 67:1606-13. doi: 10.1136/gutjnl-2017-314461

20. Leonard MM, Silvester JA, Leffler D, Fasano A, Kelly CP, Lewis SK, et al. Evaluating responses to gluten challenge: a randomized, double-blind, 2-dose gluten challenge trial. Gastroenterology (2021) 160:720-33. doi: 10.1053/ j.gastro.2020.10.040

21. Anderson RP, Degano P, Godkin AJ, Jewell DP, Hill AV. In vivo antigen challenge in celiac disease identifies a single transglutaminase-modified peptide as the dominant A-gliadin T-cell epitope. Nat Med (2000) 6:33742. doi: $10.1038 / 73200$

22. Anderson RP, Van Heel DA, Tye-Din JA, Barnardo M, Salio M, Jewell DP, et al. T cells in peripheral blood after gluten challenge in coeliac disease. Gut (2005) 54:1217-23. doi: 10.1136/gut.2004.059998

23. Ontiveros N, Tye-Din JA, Hardy MY, Anderson RP. Ex-vivo whole blood secretion of interferon (IFN)-gamma and IFN-gamma-inducible protein-10 measured by enzyme-linked immunosorbent assay are as sensitive as IFNgamma enzyme-linked immunospot for the detection of gluten-reactive $\mathrm{T}$ cells in human leucocyte antigen (HLA)-DQ2.5(+) -associated coeliac disease. Clin Exp Immunol (2014) 175:305-15. doi: 10.1111/cei.12232

24. Tye-Din JA, Daveson AJM, Goldstein KE, Hand HL, Neff KM, Goel G, et al. Patient factors influencing acute gluten reactions and cytokine release in treated coeliac disease. BMC Med (2020) 18:362. doi: 10.1186/s12916-02001828-y

25. Goel G, King T, Daveson AJ, Andrews JM, Krishnarajah J, Krause R, et al. Epitope-specific immunotherapy targeting CD4-positive $\mathrm{T}$ cells in coeliac disease: two randomised, double-blind, placebo-controlled phase 1 studies. Lancet Gastroenterol Hepatol (2017) 2:479-93. doi: 10.1016/S2468-1253(17) 30110-3

26. Han A, Newell EW, Glanville J, Fernandez-Becker N, Khosla C, Chien YH, et al. Dietary gluten triggers concomitant activation of CD4+ and CD8+ alphabeta T cells and gammadelta T cells in celiac disease. Proc Natl Acad Sci USA (2013) 110:13073-8. doi: 10.1073/pnas.1311861110

27. Van Wanrooij RL, Muller DM, Neefjes-Borst EA, Meijer J, Koudstaal LG, Heideman DA, et al. Optimal strategies to identify aberrant intra-epithelial lymphocytes in refractory coeliac disease. J Clin Immunol (2014) 34:828-35. doi: 10.1007/s10875-014-0075-7

28. Cellier C, Bouma G, Van Gils T, Khater S, Malamut G, Crespo L, et al. Safety and efficacy of AMG 714 in patients with type 2 refractory coeliac disease: a phase 2a, randomised, double-blind, placebo-controlled, parallel-group study. Lancet Gastroenterol Hepatol (2019) 4:960-70. doi: 10.1016/S2468-1253(19) 30265-1

29. Cheminant M, Bruneau J, Malamut G, Sibon D, Guegan N, Van Gils T, et al. NKp46 is a diagnostic biomarker and may be a therapeutic target in gastrointestinal T-cell lymphoproliferative diseases: a CELAC study. Gut (2019) 68:1396-405. doi: 10.1136/gutjnl-2018-317371

30. Atlas DS, Rubio-Tapia A, Van Dyke CT, Lahr BD, Murray JA. Capsule endoscopy in nonresponsive celiac disease. Gastrointest Endosc (2011) 74:1315-22. doi: 10.1016/j.gie.2011.05.049

31. Caio G, Volta U, Sapone A, Leffler DA, De Giorgio R, Catassi C, et al. Celiac disease: a comprehensive current review. BMC Med (2019) 17:142. doi: 10.1186/ s12916-019-1380-Z 
32. Ting YT, Dahal-Koirala S, Kim HSK, Qiao S-W, Neumann RS, Lundin KE, et al. A molecular basis for the T cell response in HLA-DQ2. 2 mediated celiac disease. Proc Natl Acad Sci USA (2020) 117:3063-73. doi: 10.1073/ pnas. 1914308117

33. Bodd M, Kim CY, Lundin KE, Sollid LM. T-cell response to gluten in patients with HLA-DQ2.2 reveals requirement of peptide-MHC stability in celiac disease. Gastroenterology (2012) 142:552-61. doi: 10.1053/j.gastro.2011.11.021

34. Daveson AJM, Popp A, Taavela J, Goldstein KE, Isola J, Truitt KE, et al. Baseline quantitative histology in therapeutics trials reveals villus atrophy in most patients with coeliac disease who appear well controlled on gluten-free diet. GastroHep (2020) 2:22-30. doi: 10.1002/ygh2.380

35. Al-Toma A, Goerres MS, Meijer JW, Pena AS, Crusius JB, Mulder CJ. Human leukocyte antigen-DQ2 homozygosity and the development of refractory celiac disease and enteropathy-associated T-cell lymphoma. Clin Gastroenterol Hepatol (2006) 4:315-19. doi: 10.1016/j.cgh.2005.12.011

36. Biagi F, Schiepatti A, Malamut G, Marchese A, Cellier C, Bakker SF, et al. PROgnosticating COeliac patieNts SUrvivaL: the PROCONSUL score. PloS One (2014) 9:e84163. doi: 10.1371/journal.pone.0084163

37. Murray JA, Moore SB, Van Dyke CT, Lahr BD, Dierkhising RA, Zinsmeister AR, et al. HLA DQ gene dosage and risk and severity of celiac disease. Clin Gastroenterol Hepatol (2007) 5:1406-12. doi: 10.1016/j.cgh.2007.08.013

38. Catassi C, Alaedini A, Bojarski C, Bonaz B, Bouma G, Carroccio A, et al. The overlapping area of non-celiac gluten sensitivity (NCGS) and wheat-sensitive irritable bowel syndrome (IBS): an update. Nutrients (2017) 9:1268. doi: $10.3390 /$ nu9111268

39. El-Salhy M, Hatlebakk JG, Gilja OH, Hausken T. The relation between celiac disease, nonceliac gluten sensitivity and irritable bowel syndrome. Nutr J (2015) 14:92. doi: 10.1186/s12937-015-0080-6

40. Malamut G, Cellier C. Refractory celiac disease. Gastroenterol Clin North Am (2019) 48:137-44. doi: 10.1016/j.gtc.2018.09.010

41. Husby S, Murray JA, Katzka DA. AGA clinical practice update on diagnosis and monitoring of celiac disease-changing utility of serology and histologic measures: expert review. Gastroenterology (2019) 156:885-9. doi: 10.1053/ j.gastro.2018.12.010

42. Rubio-Tapia A, Hill ID, Kelly CP, Calderwood AH, Murray JA, American College of Gastroenterology. ACG clinical guidelines: diagnosis and management of celiac disease. Am J Gastroenterol (2013) 108:656-76; quiz 677. doi: 10.1038/ajg.2013.79

43. Diez-Sampedro A, Olenick M, Maltseva T, Flowers M. A gluten-free diet, not an appropriate choice without a medical diagnosis. J Nutr Metab (2019) 2019:2438934. doi: 10.1155/2019/2438934

44. Brown NK, Guandalini S, Semrad C, Kupfer SS. A clinician's guide to celiac disease HLA genetics. Am J Gastroenterol (2019) 114:1587-92. doi: 10.14309/ ajg. 0000000000000310

45. Hadithi M, Von Blomberg BM, Crusius JB, Bloemena E, Kostense PJ, Meijer JW, et al. Accuracy of serologic tests and HLA-DQ typing for diagnosing celiac disease. Ann Intern Med (2007) 147:294-302. doi: 10.7326/0003-4819147-5-200709040-00003

46. Syage JA, Green PHR, Khosla C, Adelman DC, Sealey-Voyksner JA, Murray JA. Latiglutenase treatment for celiac disease: symptom and quality of life improvement for seropositive patients on a gluten-free diet. GastroHep (2019) 1:293-301. doi: 10.1002/ygh2.371

47. Leffler DA, Kelly CP, Abdallah HZ, Colatrella AM, Harris LA, Leon F, et al. A randomized, double-blind study of larazotide acetate to prevent the activation of celiac disease during gluten challenge. Am J Gastroenterol (2012) 107:155462. doi: 10.1038/ajg.2012.211

48. Petersen J, Van Bergen J, Loh KL, Kooy-Winkelaar Y, Beringer DX, Thompson A, et al. Determinants of gliadin-specific T cell selection in celiac disease. J Immunol (2015) 194:6112-22. doi: 10.4049/jimmunol.1500161
49. Christophersen A, Ráki M, Bergseng E, Lundin KE, Jahnsen J, Sollid LM, et al. Tetramer-visualized gluten-specific CD4+ T cells in blood as a potential diagnostic marker for coeliac disease without oral gluten challenge. $U$ Eur Gastroenterol J (2014) 2:268-78. doi: 10.1177/2050640614540154

50. Raki M, Fallang LE, Brottveit M, Bergseng E, Quarsten H, Lundin KE, et al. Tetramer visualization of gut-homing gluten-specific $\mathrm{T}$ cells in the peripheral blood of celiac disease patients. Proc Natl Acad Sci USA (2007) 104:2831-6. doi: 10.1073/pnas.0608610104

51. Risnes LF, Christophersen A, Dahal-Koirala S, Neumann RS, Sandve GK, Sarna VK, et al. Disease-driving CD4+ T cell clonotypes persist for decades in celiac disease. J Clin Invest (2018) 128:2642-50. doi: 10.1172/ JCI98819

52. Yao Y, Zia A, Neumann RS, Pavlovic M, Balaban G, Lundin KEA, et al. T cell receptor repertoire as a potential diagnostic marker for celiac disease. Clin Immunol (2020) 222:108621. doi: 10.1016/j.clim.2020.108621

53. Adelman DC, Murray J, Wu TT, Maki M, Green PH, Kelly CP. Measuring change in small intestinal histology in patients with celiac disease. Am J Gastroenterol (2018) 113:339-47. doi: 10.1038/ajg.2017.480

54. Leffler D, Schuppan D, Pallav K, Najarian R, Goldsmith JD, Hansen J, et al. Kinetics of the histological, serological and symptomatic responses to gluten challenge in adults with coeliac disease. Gut (2013) 62:996-1004. doi: 10.1136/ gutjnl-2012-302196

55. Di Sabatino A, Vanoli A, Giuffrida P, Luinetti O, Solcia E, Corazza GR. The function of tissue transglutaminase in celiac disease. Autoimmun Rev (2012) 11:746-53. doi: 10.1016/j.autrev.2012.01.007

56. Reunala T, Salmi TT, Hervonen K, Kaukinen K, Collin P. Dermatitis herpetiformis: a common extraintestinal manifestation of coeliac disease. Nutrients (2018) 10:602. doi: 10.3390/nu10050602

57. Therrien A, Kelly CP, Silvester JA. Celiac disease: extraintestinal manifestations and associated conditions. J Clin Gastroenterol (2020) 54:821. doi: 10.1097/MCG.0000000000001267

58. Goel G, Daveson AJM, Hooi CE, Tye-Din JA, Wang S, Szymczak E, et al. Serum cytokines elevated during gluten-mediated cytokine release in coeliac disease. Clin Exp Immunol (2020) 199:68-78. doi: 10.1111/cei.13369

59. Tye-Din JA, Skodje GI, Sarna VK, Dzuris JL, Russell AK, Goel G, et al. Cytokine release after gluten ingestion differentiates coeliac disease from selfreported gluten sensitivity. U Eur Gastroenterol J (2020) 8:108-18. doi: $10.1177 / 2050640619874173$

60. Zühlke S, Risnes LF, Dahal-Koirala S, Christophersen A, Sollid LM, Lundin KE. CD38 expression on gluten-specific $\mathrm{T}$ cells is a robust marker of gluten reexposure in coeliac disease. U Eur Gastroenterol J (2019) 7:1337-44. doi: $10.1177 / 2050640619874183$

61. Ludvigsson JF, Ciacci C, Green PH, Kaukinen K, Korponay-Szabo IR, Kurppa $\mathrm{K}$, et al. Outcome measures in coeliac disease trials: the Tampere recommendations. Gut (2018) 67:1410-24. doi: 10.1136/gutjnl-2017-314853

Conflict of Interest: The authors declare that this study was funded by Takeda Pharmaceutical Company Ltd. All authors were employees of Takeda Pharmaceuticals Inc. Co., and were responsible for the content, collection, analysis, interpretation of data, preparation of this article and the decision to submit it for publication.

Copyright (C) 2021 Smithson, Siegelman, Oki, Maxwell and Leffler. This is an open-access article distributed under the terms of the Creative Commons Attribution License (CC BY). The use, distribution or reproduction in other forums is permitted, provided the original author(s) and the copyright owner(s) are credited and that the original publication in this journal is cited, in accordance with accepted academic practice. No use, distribution or reproduction is permitted which does not comply with these terms. 